\title{
O amor à política em Hannah Arendt
}

\author{
Hannah Arendt's love of politics
}

A presente Dissertação apresentou o pensamento político de Hannah Arendt como sendo capaz de contribuir com novos conceitos que, de certa forma, superam os cânones habituais da filosofia ocidental. Num primeiro momento, o trabalho discorreu sobre os fundamentos da reflexão política mais madura de Arendt, o locus de sua compreensão em torno daquilo que se denomina totalitarismo. O totalitarismo, segundo o pensamento arendtiano, seria, ele mesmo, o meio responsável pela desnaturação da política. Num segundo momento do trabalho, analisou-se o posicionamento da política no pensamento de Hannah Arendt, rejeitando-se, desse modo, a maneira como a política é habitualmente entendida pela modernidade. Objetivou-se apresentar o modo pelo qual a pensadora judia faz emergir o conceito de liberdade no âmbito da política. Em um terceiro momento, o trabalho voltou-se para a questão do poder, enquanto avesso, ou seja, o "outro" da violência. Foram discutidos os conceitos de poder e violência, sendo assinalada a disparidade presente entre ambos. Em um quarto momento do estudo, a questão política foi interpretada como sendo liberdade plural, e chega-se à conclusão sobre a relação existente entre a proposta arendtiana e a filosofia clássica grega. Priorizou-se, no caso, a obra $O$ que é a política? Por ser a mais significativa de Hannah Arendt no que concerne ao tema. Após essa explanação, foram abordadas as relações estreitas entre política, libe d́dade e

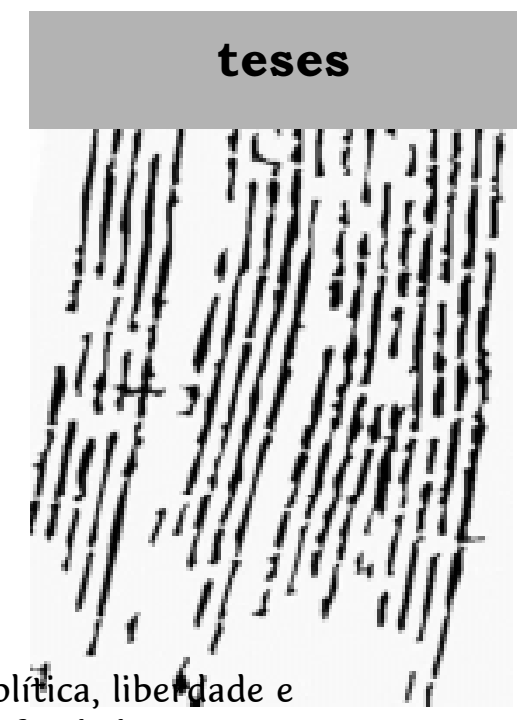
dignidade. A ética política fundada na noção de dignidade é, para Hannah Arendt, um elemento de harmonização nas relações humanas, já que recusa tudo que minimize a condição humana. Por fim, a abordagem acerca daquilo que se caracteriza como condição humana foi, particularmente enfatizada, já que o pensamento arendtiano estabelece como central essa questão.

Paulo Petry

Dissertação de Mestrado, 2002 Programa de Pós-Graduação em Filosofia da Universidade Gama Filho, Rio de Janeiro. <ppetry@zipmail.com.br>

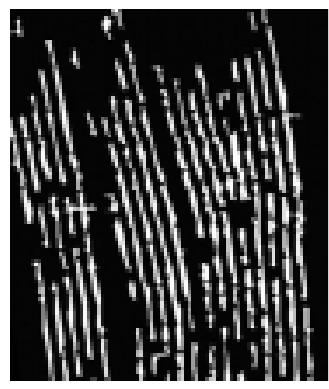

PALAVRAS-CHAVE: Política; formação de conceitos. KEY WORDS: Politics; concept formation.

PALABRAS CLAVE: Politica; formación de conceptos. 